J. Product. \& Dev., 14(2): 291 - 312 (2009)

\title{
EFFECT OF ORGANIC, CHEMICAL AND BIOFERTILIZATION ON GROWTH, YIELD AND CHEMICAL CONSTITUENTS OF FENNEL (Foeniculum vulgare, Mill.) PLANTS.
}

\author{
A. A. EL-Sayed;* A. S. El-Leithy* ; R. M. Moustafa ** and H. M. Harb** \\ *Ornamental Horticulture Department, Faculty of Agriculture, Cairo \\ University, Egypt. \\ ** Department of Medicinal and Aromatic Plants, Agriculture Research \\ Center, Egypt.
}

\section{ABSTRACT}

This study was conducted during two seasons of 2003/2004 and $2004 / 2005$ to study the effect of poultry manure at $\left(5,10\right.$ or $20 \mathrm{~m}^{3} / \mathrm{fad}$.), NPK at (100:100:50 and 200:200:100 kg/ fad.) and Bio-fertilizer (active dry yeast at 2 or $4 \mathrm{~g} / \mathrm{L}$, vitamin $B_{1}$ at 25 or 50ppm and nitrobein as bio source of nitrogen at 500 or $1000 \mathrm{~g} / \mathrm{fad}$. ) on growth, yield, oil production and chemical composition of fennel (Foeniculum vulgare, Mill.) plants. The results showed that poultry manure application at 10 or $20 \mathrm{~m}^{3} / \mathrm{fad}$ significantly increased plant height, number of main branches, fresh and dry weights of leaves and stems, number of umbels/ plant, fruit yield, essential oil percentage and oil yield/ plant in the two seasons. The best results were obtained by these two doses (10 or $20 \mathrm{~m}^{3} / \mathrm{fad}$.). They increased total carbohydrates percentages in different plant organs and increased $\alpha$ pinene, $\beta$ pinene, anise aldehyde, fenchone, anethole and decreased estragole (Methyl chavicol) percentages in the oil.

Chemical and bio-fertilizers had a significant effect on vegetative growth characteristics (plant height, number of branches/ plant, fresh and dry weights of leaves and stems) number of umbels/ plant, fruit yield, oil percentage and oil yield/ plant in both seasons. The most effective treatment was NPK at (200:200:100 kg/ fad.) followed by active dry yeast at 2 or $4 \mathrm{~g} / \mathrm{L}$ as compared with nitrobein at 500 or $1000 \mathrm{~g} / \mathrm{fad}$. which gave the lowest values. This treatment resulted in high percentage of carbohydrates in leaves, stems and fruits in the two seasons.

Interaction between poultry manure, chemical and bio-fertilizers had a significant effect on both vegetative growths, fruit yield/ plant and oil production in both seasons. The interaction between these treatments increased anethol content in the oil and total carbohydrates percentages in different plant organs.

Key words: Poultry manure, chemical fertilizers, bio-fertilizers, oil yield, chemical constituents, fennel, Foeniculum vulgare, Mill. plant. 


\section{INTRODUCTION}

Fennel (Foeniculum vulgare, L.) belongs to family Apiaceae (Umbelliferae). The volatile oil is composed of the following constituents: $\alpha$ pinene, camphor, d-phyllandrene, dipentene, d. fenchone, anethole, methyl chavicol, anisaldehyde, feniculin and anisic acid, (Guenther, 1961). Fennel is used as a popular flavoring agent in culinary preparation, bread, and pastry confectionery. Further more, the fruits and essential oil of fennel are used as diuretic or expectorant and to relieve spasms as well as flatulence and to promote secretions. Morelli et al. (1983) reported that, fennel exhibits carminative, diuretic, ant inflammatory, antimicrobial galactogogue and oestrogenic activities. Poultry manure affecting growth, yield and chemical constituents of many aromatic plants; Abd El-Latif (2006) on Salvia officinalis and Mona et al. (2008) on fennel and salvia plants.

Chemical fertilization was studied by many authors; Sakr (2001) on Mentha piperita; Mohsen (2002) on Ocimum basilicum L.; Abd EL-Azim (2003) and Abd EL- Latif (2006) on Salvia officinalis, L.

Bio-fertilizers application affecting growth, yield and chemical constituents of many aromatic plants; Salman (2004) on Ocimum basilicum; Abd EL-Latif (2006) on Salvia officinalis, L and Abd EL- Ghani (2007) on Rosmarinus officinalis, L.

\section{MATERIALS AND METHODS}

The present study was carried out during two successive seasons of 2003/ 2004 and 2004/ 2005 at the experimental Farm of EL-Kassassin station, Agriculture Research Center, to study the effect of organic manure (poultry manure), chemical fertilizers (NPK) and bio-fertilizers (Active dry yeast, vitamin B1 and nitrobein) on growth, yield, oil production and chemical composition of fennel (Foeniculum vulgare, Mill) plants.

Seeds (fruits) obtained from Medicinal and Aromatic Plants Research Center, Dokki, Giza, were sown on 15 th November in the two seasons in sandy soil at a distance of $30 \mathrm{~cm}$ between hills (one plant/ hill) and $100 \mathrm{~cm}$ between rows. The layout of the experiment was split plot design as it included 24 treatments with three replicates. Each replicate contained 20 plants.

The physical and chemical properties of the experimental area are shown in Tables A, B.

Plants in the main experimental plots were fertilized by poultry manure at 5,10 and $20 \mathrm{~m}^{3} /$ fad./ season which added 15 days before sowing date. 
Table A. Physical analysis of soil

\begin{tabular}{lccc}
\hline Sand $\%$ & Clay $\%$ & Silt $\%$ & Texture \\
\hline 89.92 & 4.00 & 6.08 & sandy \\
\hline \hline
\end{tabular}

Table B. Chemical properties of the soil chemical analysis

\begin{tabular}{|c|c|c|c|c|c|c|c|c|c|c|c|}
\hline $\mathbf{N}$ & $\mathbf{P}$ & $\mathbf{K}$ & $\mathrm{SO}_{4}^{-}$ & $\mathrm{Cl}^{-}$ & $\mathrm{HCO}_{3}^{-}$ & $\mathrm{Mg}^{++}$ & $\mathrm{Ca}^{++}$ & $\mathbf{K}^{+}$ & $\mathrm{Na}^{+}$ & & \\
\hline \multicolumn{3}{|c|}{ ppm } & & $\mathrm{eq} / \mathrm{L}$ & & & & & & $\begin{array}{l}\text { E.C. } \\
\text { mmhos/c }\end{array}$ & ph \\
\hline 81.00 & 23.00 & 108.00 & 0.97 & 0.50 & 1.00 & 0.40 & 1.00 & 0.31 & 0.76 & 2.70 & 8.10 \\
\hline
\end{tabular}

Table C. The chemical analysis of organic fertilizer applied at 2003/2004 and 2004/2005 seasons.

\begin{tabular}{lcc}
\hline Organic manure characteristics & \multicolumn{2}{c}{ Poultry manure (PM) } \\
\cline { 2 - 3 } & $\mathbf{2 0 0 3 / 2 0 0 4}$ & $\mathbf{2 0 0 4 / 2 0 0 5}$ \\
\hline Weight of $\mathbf{~ l m}^{\mathbf{3}}(\mathbf{k g})$ & 689 & 538 \\
Moisture content $(\%)$ & 6.90 & 9.54 \\
Organic matter (\%) & 93.95 & 81.91 \\
Organic carbon \% & 36.93 & 50.61 \\
Total N\% & 2.30 & 3.66 \\
C:N ratio & $15.4: 1$ & $13.2: 1$ \\
NH3-N(ppm) & 3021.8 & 3489.9 \\
NO3-N(ppm) & 174.9 & 224.6 \\
Total P(\%) & 1.13 & 0.52 \\
Total K(\%) & 0.75 & 1.74 \\
Fe(ppm) & 1609.35 & 1724.5 \\
Mn(ppm) & 122.3 & 162.4 \\
Zn(ppm) & 82.5 & 85.4 \\
Cu(ppm) & 35.80 & 52.30 \\
\hline
\end{tabular}

Plants in sub plots were treated with NPK fertilizers at (100:100:50 or 200:200:100 kg/ fad./ season) using ammonium sulphate $(20.6 \% \mathrm{~N})$, calcium superphosphate $\left(15.5 \% \quad \mathrm{P}_{2} \mathrm{O}_{5}\right)$ and potassium sulphate $\left(48 \% \mathrm{~K}_{2} \mathrm{O}\right)$ at two equal doses, the first dose was applied 45 days after sowing and the second was added after 30 days from the first one. Active dry yeast at 2, $4 \mathrm{~g} / \mathrm{L}$ and Vitamin $\mathrm{B}_{1}$ at $25,50 \mathrm{ppm}$ were added as spraying twice per season, the first was applied after 45 days from sowing, and the second was applied after 15 days from the first one. Nitrobein as a bio source of nitrogen was applied during sowing seeds at 500 or $1000 \mathrm{~g} / \mathrm{fad} . / \mathrm{season}$.

Data on plant height, number of main branches/ plant, fresh and dry weights of leaves and stems ( $\mathrm{g} /$ plant during milky stage), number of umbels/ plant, fruit yield (g/ plant). The samples were dried in an electric oven at $70^{\circ} \mathrm{C}$ till a constant weight. Essential oil percentage and oil yield (ml)/ plant were 
determined as described by British Pharmacopoeia (1963). Gas Liquid Chromatography (GLC) analysis of essential oil was performed using Hewlett Packard Gas Chromatograph apparatus with the following specifications: Capillary column Ultra 2(cross- linked 5\% ph.me., silicon) 25m X0.32 m X0.52 $\mu \mathrm{L}$ film thickness. Nitrogen, hydrogen and air flow rates 30,30 and $300 \mathrm{ml} / \mathrm{min}$, respectively. Injection temperature of $250^{\circ} \mathrm{C}$, Detector temperature of $275^{\circ} \mathrm{C}$, oven program of $70^{\circ} \mathrm{C}$ to $220^{\circ} \mathrm{C}$ increasing the temperature by $10^{\circ} \mathrm{C} / \mathrm{min}$. Chart speed was $/ \mathrm{cm} / \mathrm{min}$. as described by Bunzen et al.(1969) and total carbohydrates contents were determined as described by Herbert et al.(1971).

The statistical analysis was carried out using Least Significant Differences (LSD) test at 0.05\% according to Snedecor and Corchran (1972).

\section{RESULTS AND DISCUSSION}

\section{Plant height:}

Data in Table 1 showed that, poultry manure at 10 and $20 \mathrm{~m}^{3} / \mathrm{fad}$. had a significant effect on plant height compared to poultry manure at $5 \mathrm{~m}^{3} / \mathrm{fad}$. in the two seasons. Similar results were obtained by Abd- EL-Latif (2006) on Salvia officinalis and Mona et al. (2008) on fennel and salvia plants. They showed that organic manure application increased plant height.

Concerning the effect of chemical and bio-fertilizers on plant height, the data in Table 1 showed that, the high rate of NPK (200:200:100 kg/ fad.) significantly increased plant height compared with NPK at 100:100:50 kg/ fad.). Also, the highest rates of bio-fertilization treatments significantly increased plant height compared with the lowest concentration in both seasons. These results are in harmony with those obtained by Amber et al. (2008) on basil plant showed that, increasing fertilizer dosage increased plant height. Also, Abd- EL-Latif (2006) on Salvia officinalis found that active dry yeast application increased plant height.

Concerning interaction between organic, chemical and bio-fertilizers, the results showed that, NPK fertilization at (200:200:100 kg/ fad.) plus poultry manure at $20 \mathrm{~m}^{3} / \mathrm{fad}$. gave the tallest plants compared with nitrobein at $500 \mathrm{~g} /$ fad. plus poultry manure at $5 \mathrm{~m}^{3} /$ fad. which gave the shortest plants.

\section{Number of main branches/plant:}

Data in Table 1 showed that, there were significant differences on number of main branches per plant due to poultry manure application at 10 or $20 \mathrm{~m}^{3} / \mathrm{fad}$., compared with poultry manure at $5 \mathrm{~m}^{3} / \mathrm{fad}$. in the two seasons. The best results were obtained by poultry manure at $20 \mathrm{~m}^{3} / \mathrm{fad}$. as compared with the other two rates $\left(5\right.$ or $10 \mathrm{~m}^{3} / \mathrm{fad}$.). These results are in harmony with those obtained by Abd-EL-Latif (2006) on Salvia officinalis, L and Mona et al. (2008) on fennel and salvia plants. 
Concerning chemical and bio-fertilizers, data presented in Table 1 showed that, NPK at (100:100:50) and (200:200:100) kg/ fad. gave the highest number of main branches in both seasons, followed by active dry yeast at the rate of ( 2 or $4 \mathrm{~g} / \mathrm{L}$ ) compared to vitamin $\mathrm{B}_{1}$ at $(25$ or $50 \mathrm{ppm})$ and nitrobein at (500 or $1000 \mathrm{~g} / \mathrm{fad}$.) . These results are in accordance with the findings obtained by Ali (2001) on Calendula officinalis and Abd EL-Latif (2006) on Salvia officinalis, they found that, active dry yeast significantly increased number of main branches.

Concerning the interaction between poultry manure, chemical and biofertilizers, NPK at (200:200:100) $\mathrm{kg} / \mathrm{fad}$., plus poultry manure at $20 \mathrm{~m}^{3} / \mathrm{fad}$., significantly increased number of main branches compared to nitrobein at $500 \mathrm{~g} /$ fad. plus poultry manure at $5 \mathrm{~m}^{3} / \mathrm{fad}$., which gave the lowest number of branches/ plant.

\section{Leaves fresh and dry weights (g/plant):}

Data presented in Table 2 showed that poultry manure at 10 and $20 \mathrm{~m}^{3} /$ fad. significantly increased leaves fresh and dry weights in both two seasons compared with $5 \mathrm{~m}^{3} /$ fad.. Poultry manure at $20 \mathrm{~m}^{3} /$ fad. was the most effective treatment which gave the heaviest fresh and dry weights in both two seasons. These results are in harmony with those obtained by Abd EL-Latif (2006) on Salvia officinalis, L., and Mona et al. (2008) on fennel and salvia plants.

Concerning the effect of NPK and bio-fertilizers, NPK treatments showed a significant increment in leaves fresh and dry weights in the first and second seasons, followed by active dry yeast at ( 2 or $4 \mathrm{~g} / \mathrm{L}$ ), vitamin $\mathrm{B}_{1}$ treatments at $(25$ or $50 \mathrm{ppm})$ compared with nitrobein treatments which gave the lowest fresh and dry weights of leaves in both seasons. The most effective treatment was NPK at 200:200:100 kg/ fad. in both season, which gave the heaviest fresh and dry weights. Similar results were obtained by Abd EL- Azim (2003) and Abd EL- Latif (2006) on Salvia officinalis. L. They showed that NPK fertilization increased leaves fresh and dry weights/ plant. Also, Salman (2004) on Osmium basilicum and Abd EL-Latif (2006) on Salvia officinalis.L. They showed that, active dry yeast increased leaves fresh and dry weights/ plant.

Interaction between organic, chemical and bio-fertilizers, significantly affected leaves fresh and dry weights/ plants. In both seasons, the heaviest leaves fresh and dry weights were obtained from plants treated with NPK at 200:200:100 kg/ fad, plus poultry manure at $20 \mathrm{~m}^{3} / \mathrm{fad}$, while the lowest fresh and dry weights were obtained for nitrobein at $500 \mathrm{~g} / \mathrm{fad}$, plus poultry manure at $5 \mathrm{~m}^{3} / \mathrm{fad}$.

\section{Stems fresh and dry weights (g/ plant):}

Data recorded in Table 3 showed that, poultry manure at 10 and $20 \mathrm{~m}^{3} /$ fad., significantly increased stems fresh and dry weights in both two seasons 
compared with $5 \mathrm{~m}^{3} /$ fad.. Poultry manure at $20 \mathrm{~m}^{3} /$ fad. was the most effective treatment which gave the heaviest stems fresh and dry weights in both two seasons. Similar results are obtained by Abd EL-Latif (2006) on Salvia officinalis, L. and Mona et al. (2008) on fennel and salvia plants. They found that, poultry manure at $20 \mathrm{~m}^{3} / \mathrm{fad}$., increased stems fresh and dry weights/ plant.

Both NPK and bio-fertilizers application significantly increased stems fresh and dry weights in the first and second seasons. The most effective treatments were NPK at (200:200:100) and (100:100:50) kg/ fad. in both seasons, which gave the heaviest stems fresh and dry weights followed by active dry yeast at 2 or $4 \mathrm{~g} / \mathrm{L})$, vitamin $\mathrm{B}_{1}$ at $(25$ or $50 \mathrm{ppm})$ compared with nitrobein at 500 or $1000 \mathrm{~g} / \mathrm{fad}$. which gave the lowest values. These results are in accordance with the findings of Morsy (1999) on Thymus vulgaris and Abd EL-Latif (2006) on Salvia officinalis. L. They showed that, NPK fertilization increased stems fresh and dry weights.

Interaction between poultry manure, NPK and bio-fertilizers application had a significant effect on stems fresh weight in the first and second seasons. NPK application at (200:200:100) kg/ fad., plus poultry manure at $20 \mathrm{~m}^{3} / \mathrm{fad}$., gave the heaviest stems fresh and dry weights compared with nitrobein at $500 \mathrm{~g} /$ fad. plus poultry manure at $5 \mathrm{~m}^{3} /$ fad., which gave the lowest values in both two seasons.

\section{Number of umbels per plant:}

Data presented in Table 4 showed that, poultry manure significantly increased number of umbels in both seasons. Poultry manure at 20 followed by $10 \mathrm{~m}^{3} / \mathrm{fad}$. were the most effective treatment which gave the highest values compared to poultry manure at $5 \mathrm{~m}^{3} /$ fad. which gave the lowest values in the first and second seasons. Similar results are obtained by Mona et al. (2008) on fennel plants.

Concerning the effect of NPK and bio-fertilizers, the data showed that, NPK and bio-fertilizers significantly increased number of umbels/ plant in both two seasons. The best results were obtained by NPK at (200:200:100), (100:100:50) $\mathrm{kg} /$ fad. and active dry yeast at $\left(2\right.$ or $4 \mathrm{~g} / \mathrm{L}$ ) followed by vitamin $\mathrm{B}_{1}$ at $(25,50 \mathrm{ppm})$ compared with nitrobein at (500 and $100 \mathrm{~g} / \mathrm{fad}$.) which gave the lowest number of umbels/ plant in both two seasons.

Regarding the interaction effect between poultry manure, NPK and biofertilizers. The application of NPK at (200:200:100) kg/ fad. and poultry manure at $20 \mathrm{~m}^{3} /$ fad. gave the highest number of umbels/plant compared with nitrobein at $500 \mathrm{~g} / \mathrm{fad}$. plus poultry manure at $5 \mathrm{~m}^{3} / \mathrm{fad}$. in the first and second seasons. These results are in agreement with those obtained by Ali (2002) on fennel, who found that, interaction between chemical and organic fertilizers increased number on umbels/plant. 


\section{Fruits yield/ plant:}

Data presented in Table 4 showed that poultry manure at 10 and $20 \mathrm{~m}^{3} /$ fad. significantly increased fruit yield/ plant in both two seasons. Poultry manure at 20 or $10 \mathrm{~m}^{3} /$ fad. gave the highest values compared to poultry manure at $5 \mathrm{~m}^{3} /$ fad. in the first and second seasons. These results are harmony with those obtained by Hammam (1996) on Pimpinella anisum and Mona et al. (2008) on fennel plant. They found that, the high rate of organic manure significantly increased fruit yield/plant.

Both NPK and bio-fertilizers application significantly increased fruit yield/plant in both two seasons. NPK at (200:200:100) and (100:100:50) kg/ fad. gave the highest fruit yield followed by active dry yeast at 4 and $2 \mathrm{~g} / \mathrm{L}$ compared with vitamin $B_{1}$ at $(25,50 \mathrm{ppm})$ and nitrobein at $(500,1000 \mathrm{~g} / \mathrm{fad}$.) in the first and second seasons. These results are in agreement with those obtained by EL Ghadban et al. (2003) on Ricinus communis, L., who found that the high rates of active dry yeast increased fruit yield /plant.

Regarding the interaction between poultry manure, NPK and biofertilizers, in the first, there was no significant effect on fruit yield /plant. In the second season, there was a significant effect on fruit yield/plant. The highest values were produced from plants treated with NPK at (200:200:100) $\mathrm{kg} / \mathrm{fad}$. plus poultry manure at $20 \mathrm{~m}^{3}$ compared to nitrobein at $500 \mathrm{~g} /$ fad. plus poultry manure at $5 \mathrm{~m}^{3} / \mathrm{fad}$. which gave the lowest value. These results are in harmony with those obtained by Ali (2002) on fennel. Who found that, organic manure plus chemical fertilization increased fruit yield.

\section{Volatile oil percentage:}

Data presented in Table 5 showed that, poultry manure at 10 or $20 \mathrm{~m}^{3} /$ fad. significantly increased volatile oil percentage in both seasons. Poultry manure at 10 or $20 \mathrm{~m}^{3} /$ fad. gradually increased volatile oil percentage compared to poultry manure at $5 \mathrm{~m}^{3} / \mathrm{fad}$. in the first and second seasons. These results are in agreement with those obtained by Jacoub (1999) on Ocimum basilicum and Thymus vulgaris and Abd EL- Latif (2006) on Salvia officinalis, L. They found that, the highest rates of poultry manure significantly increased volatile oil percentage.

NPK and bio-fertilizers significantly increased volatile oil percentage in both two seasons. The best results were obtained by NPK at (200:200:100)and (100:100:50) kg/fad., which gave the highest volatile oil percentage followed by active dry yeast at (4 and $2 \mathrm{~g} / \mathrm{L}$ ) compared with vitamin $\mathrm{B}_{1}$ at $(25,50 \mathrm{ppm})$ and nitrobein at $(500,1000 \mathrm{~g} / \mathrm{fad}$.) in the first and second seasons. These results are in harmony with those obtained by Mohsen (2002) on Ocimum basilicum. They found that, NPK fertilization significantly increased volatile oil percentage.

Interaction between poultry manure, NPK and bio-fertilizers significantly increased volatile oil percentage in both seasons. The plants treated with NPK at 
(200:200:100) $\mathrm{kg} /$ fad. plus poultry manure at $20 \mathrm{~m}^{3} /$ fad. gave the highest oil percentage compared to plants treated with nitrobin at $500 \mathrm{~g} /$ fad. plus poultry manure at $5 \mathrm{~m}^{3} / \mathrm{fad}$. in the first and second seasons. Similar results were obtained by Ali (2002) on fennel, who found that, interaction between organic manure and chemical fertilization increased volatile oil percentage.

\section{Volatile oil yield/plant:}

Data in Table 5 showed that poultry manure at 10 or $20 \mathrm{~m}^{3} / \mathrm{fad}$. gradually increased volatile oil yield/ plant compared to poultry manure at $5 \mathrm{~m}^{3} / \mathrm{fad}$. in both two seasons. These results are in according with the findings obtained by Abd EL-Latif (2006) on Salvia officinalis, L and Mona et al. (2008) on fennel and salvia plants. They showed that, the high rate of organic manure fertilization significantly increased volatile oil yield/ plant.

Both NPK and bio-fertilizers application significantly increased volatile oil yield/plant in both two seasons. The most effective treatments were NPK at (200:200:100) and (100:100:50) kg/ fad., which gave the highest volatile oil yield/ plant followed by active dry yeast at 4 and $2 \mathrm{~g} / \mathrm{L}$ compared with vitamin $\mathrm{B}_{1}$ at $(20,50 \mathrm{ppm})$ and nitrobein at $(500,100 \mathrm{~g} / \mathrm{fad}$. $)$, respectively in the first and second seasons. Similar results were obtained by Abd EL Latif (2006) on Salvia officinalis, L who found that, both NPK and active dry yeast treatments significantly increased volatile oil yield.

Interaction between poultry manure, NPK and bio-fertilizers had a significant effect on volatile oil yield/ plant in both two seasons. NPK at (200:200:100) $\mathrm{kg} / \mathrm{fad}$. plus poultry manure at $20 \mathrm{~m}^{3} / \mathrm{fad}$. gave the highest oil yield/ plant compared to plants treated with nitrobein at $500 \mathrm{~g} /$ fad. plus poultry manure at $5 \mathrm{~m}^{3} / \mathrm{fad}$., which gave the lowest essential oil yield/ plant. Similar results were obtained by Ali (2002) on fennel plants, who found that, organic manure and chemical fertilization increased volatile oil yield/ plant.

\section{GLC analysis of the essential oil:}

Data on GLC analysis of essential oil in the second season are presented in Table 6 and Figures $(1,2,3,4,5$ and 6$)$. The data showed that, poultry manure at 20 and $10 \mathrm{~m}^{3} /$ fad. gave the highest $\alpha$ - pinene, anise aldehyde, fenchone and anethole percentages but decreased estragole (methyl chavicol) compared to poultry manure at $5 \mathrm{~m}^{3} / \mathrm{fed}$. These results are in agreements with the findings obtained by Jacoub (1999) on Thymus vulgaris, showed that, the highest rate of poultry manure increased thymol and carvacrol percentages in oil. Sakr(2001) on Mentha piperita, showed that organic fertilization treatments increased menthol percentage in oil .

Both NPK and bio-fertilizers application increased the most essential oil components in the second season. NPK at (100:100:50), (200:200:100) kg/ fad. and active dry yeast at $(2,4 \mathrm{~g} / \mathrm{L})$ increased $\alpha$ pinene, $\beta$ - pinene, anise aldehyde, fenchone, menthyl chavicol (estragole), anethole percentages in the oil compared to vitamin $B_{1}$ 
Table 6. GLC analysis of essential oil of fennel (Foeniculum vulgare, Mill) plants in the second season (2004/2005).

\begin{tabular}{|c|c|c|c|c|c|c|c|c|}
\hline \multicolumn{3}{|c|}{ Treatments } & \multirow{2}{*}{ 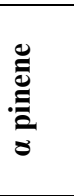 } & \multirow{2}{*}{ 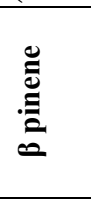 } & \multirow{2}{*}{ 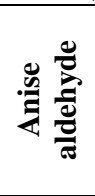 } & \multirow{2}{*}{ 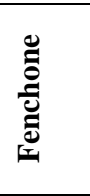 } & \multirow{2}{*}{ 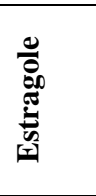 } & \multirow{2}{*}{$\frac{\stackrel{0}{0}}{\stackrel{0}{0}}$} \\
\hline $\begin{array}{c}\text { Organic } \\
\text { fertilizers }\end{array}$ & $\begin{array}{l}\text { Chemical } \\
\text { bio-fertil }\end{array}$ & & & & & & & \\
\hline \multirow{9}{*}{5} & \multirow[b]{2}{*}{ NPK (kg/fad.) } & 100:100:50 & 1.03 & 1.13 & 6.53 & 9.23 & 70.85 & 4.29 \\
\hline & & 200:200:100 & 1.15 & 1.17 & 6.93 & 9.24 & 72.75 & 4.32 \\
\hline & \multirow{2}{*}{$\begin{array}{l}\text { Active dry } \\
\text { yeast(g/L) }\end{array}$} & 2 & 0.88 & 1.10 & 6.23 & 8.80 & 68.27 & 3.93 \\
\hline & & 4 & 0.90 & 1.12 & 6.51 & 9.20 & 69.60 & 4.09 \\
\hline & \multirow{2}{*}{ Vitamin $B_{1}(p p m)$} & 25 & 0.60 & 0.70 & 5.66 & 7.30 & 66.58 & 3.62 \\
\hline & & 50 & 0.69 & 1.01 & 5.79 & 7.72 & 66.74 & 3.92 \\
\hline & \multirow{2}{*}{$\begin{array}{l}\text { Nitrobein } \\
\text { ( g/fad.) }\end{array}$} & 500 & 0.50 & 0.60 & 4.26 & 5.91 & 65.14 & 3.47 \\
\hline & & 1000 & 0.57 & 0.91 & 5.65 & 7.06 & 65.87 & 3.61 \\
\hline & Mean & & 0.79 & 0.97 & 5.95 & 8.06 & 68.23 & 3.91 \\
\hline \multirow{9}{*}{10} & \multirow{2}{*}{ NPK (kg/fad.) } & 100:100:50 & 1.58 & 1.69 & 7.88 & 11.61 & 64.78 & 8.47 \\
\hline & & 200:200:100 & 1.65 & 1.81 & 7.89 & 11.72 & 65.78 & 8.79 \\
\hline & \multirow{2}{*}{$\begin{array}{l}\text { Active dry yeast } \\
\text { g/L) }\end{array}$} & 2 & 1.43 & 1.67 & 7.59 & 9.98 & 62.41 & 6.27 \\
\hline & & 4 & 1.45 & 1.68 & 7.80 & 11.38 & 64.23 & 7.50 \\
\hline & \multirow{2}{*}{ Vitamin $B_{1}(p p m)$} & 25 & 1.27 & 1.55 & 7.32 & 9.82 & 56.79 & 5.93 \\
\hline & & 50 & 1.38 & 1.57 & 7.54 & 9.96 & 60.23 & 6.11 \\
\hline & \multirow{2}{*}{$\begin{array}{l}\text { Nitrobein } \\
\text { ( g/fad.) }\end{array}$} & 500 & 1.21 & 1.23 & 7.17 & 9.71 & 52.73 & 5.31 \\
\hline & & 1000 & 1.25 & 1.28 & 7.29 & 9.81 & 53.37 & 5.58 \\
\hline & Mean & & 1.40 & 1.56 & 7.56 & 10.50 & 53.16 & 6.75 \\
\hline \multirow{9}{*}{20} & \multirow{2}{*}{ NPK (kg/fad.) } & 100:100:50 & 3.01 & 3.77 & 8.77 & 15.01 & 48.33 & 18.05 \\
\hline & & 200:200:100 & 3.31 & 3.93 & 9.34 & 15.60 & 48.43 & 18.14 \\
\hline & \multirow{2}{*}{$\begin{array}{l}\text { Active dry } \\
\text { yeast }(g / L)\end{array}$} & 2 & 2.40 & 3.65 & 8.63 & 13.32 & 42.61 & 12.57 \\
\hline & & 4 & 2.41 & 3.69 & 8.71 & 14.36 & 44.36 & 16.46 \\
\hline & \multirow{2}{*}{ Vitamin $B_{1}(p p m)$} & 25 & 1.87 & 3.25 & 7.96 & 12.90 & 36.83 & 11.80 \\
\hline & & 50 & 2.07 & 3.42 & 8.46 & 13.22 & 38.20 & 12.51 \\
\hline & \multirow{2}{*}{$\begin{array}{l}\text { Nitrobein } \\
\text { ( g/fad.) }\end{array}$} & 500 & 1.31 & 1.81 & 7.91 & 11.83 & 29.92 & 9.45 \\
\hline & & 1000 & 1.60 & 2.34 & 7.95 & 12.27 & 33.18 & 10.75 \\
\hline & Mean & & 2.25 & 3.23 & 8.47 & 13.56 & 40.23 & 13.72 \\
\hline \multirow{8}{*}{ Mean } & \multirow{2}{*}{ NPK (kg/fad.) } & 100:100:50 & 1.87 & 2.20 & 7.73 & 11.95 & 61.32 & 10.27 \\
\hline & & 200:200:100 & 2.04 & 2.30 & 8.05 & 12.19 & 62.32 & 10.42 \\
\hline & \multirow{2}{*}{$\begin{array}{l}\text { Active dry } \\
\text { yeast(g/L) }\end{array}$} & 2 & 1.57 & 2.14 & 7.48 & 10.70 & 57.76 & 7.59 \\
\hline & & 4 & 1.59 & 2.16 & 7.67 & 11.65 & 59.40 & 9.35 \\
\hline & \multirow{2}{*}{ Vitamin $B_{1}(p p m)$} & 25 & 1.25 & 1.83 & 6.98 & 10.01 & 53.40 & 7.11 \\
\hline & & 50 & 1.38 & 1.94 & 7.26 & 10.30 & 55.06 & 7.51 \\
\hline & Nitrobein & 500 & 1.01 & 1.21 & 6.45 & 9.15 & 49.26 & 6.17 \\
\hline & ( g/fad.) & 1000 & 1.14 & 1.51 & 6.96 & 9.71 & 50.93 & 6.65 \\
\hline
\end{tabular}




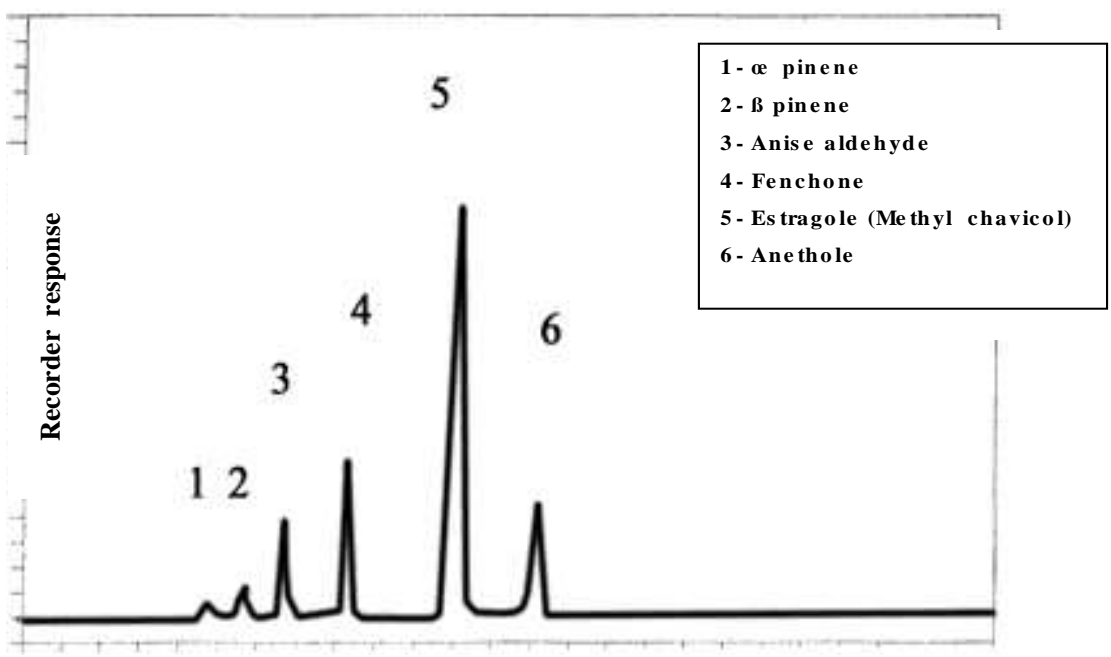

Retention time (min)

Figure 1: Chromatogram of Foencuıum vuıure, vnum essenuan oil distilled from plants fertilized with NPK at (100:100:50 Kg/fad.) plus poultry manure at $5 \mathrm{~m}^{3}$ /fad. in the second season (2004/2005).

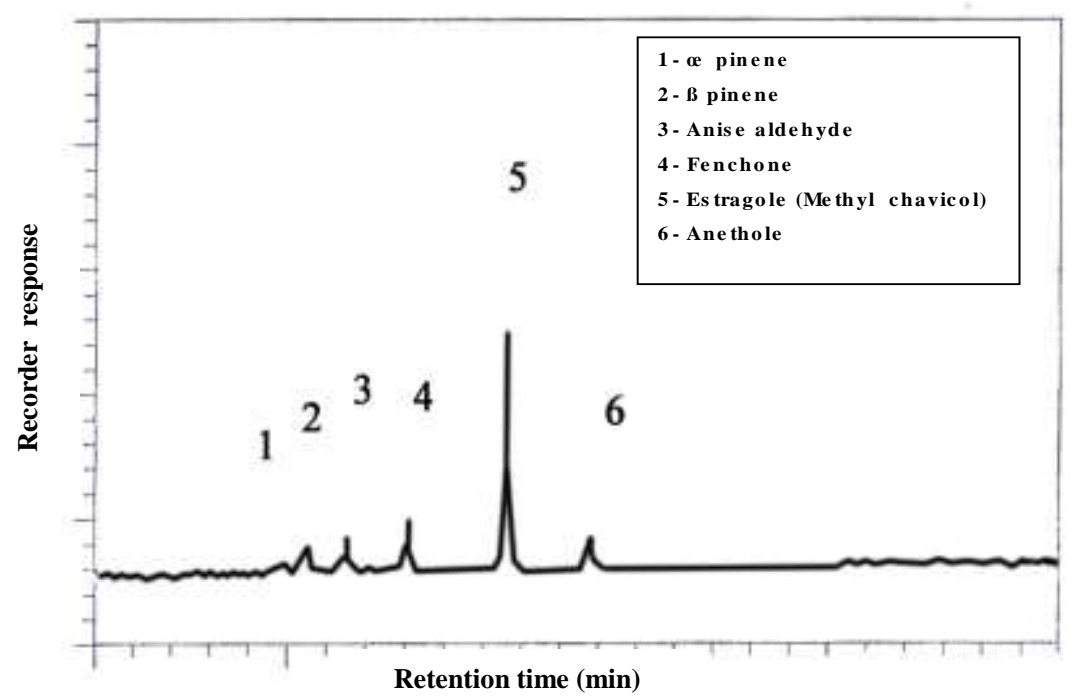

Figure 2. Chromatogram of Foeniculum vulgare, Mill essential oil distilled from plants fertilized with NPK at (200:200:100 Kg / fad.) plus poultry manure at $20 \mathrm{m3}$ / fad. in the second season (2004/2005). 


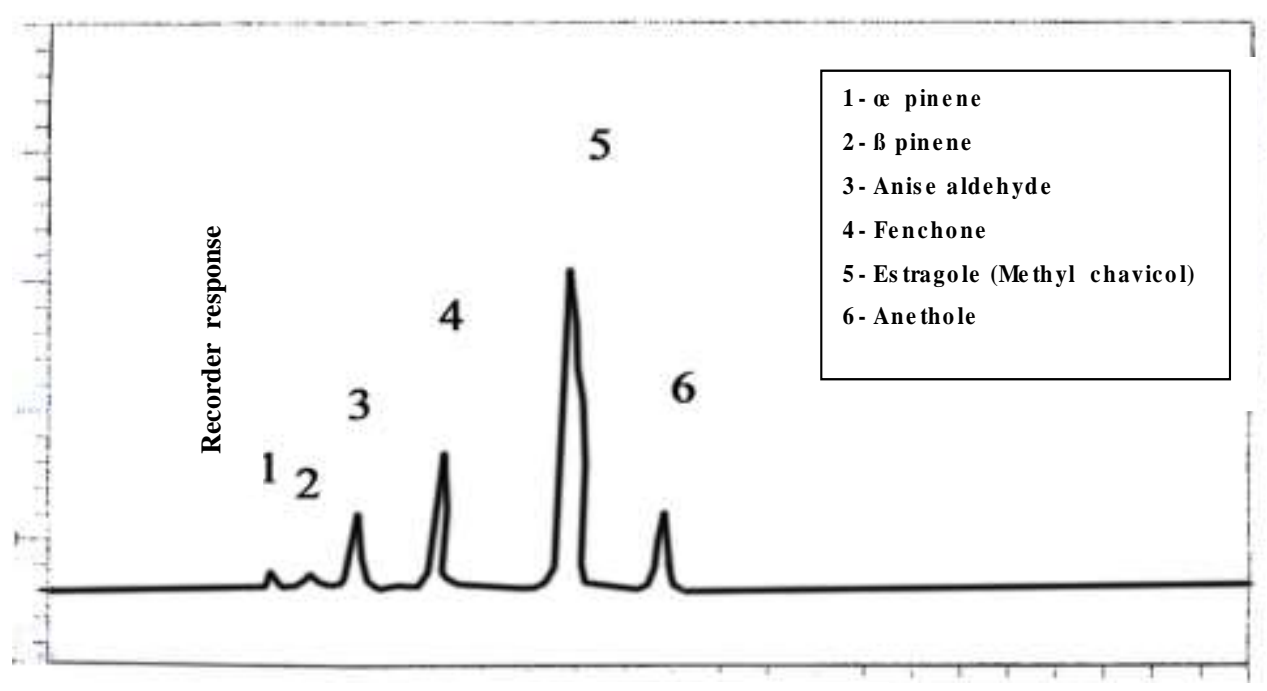

Retention time (min)

Figure 3. Chromatogram of Foeniculum vulgare, Mill essential oil distilled from plants treated with active dry yeast at $2 \mathrm{~g} / \mathrm{L}$ plus poultry manure at $5 \mathrm{m3} /$ fad. in the second season (2004/2005).

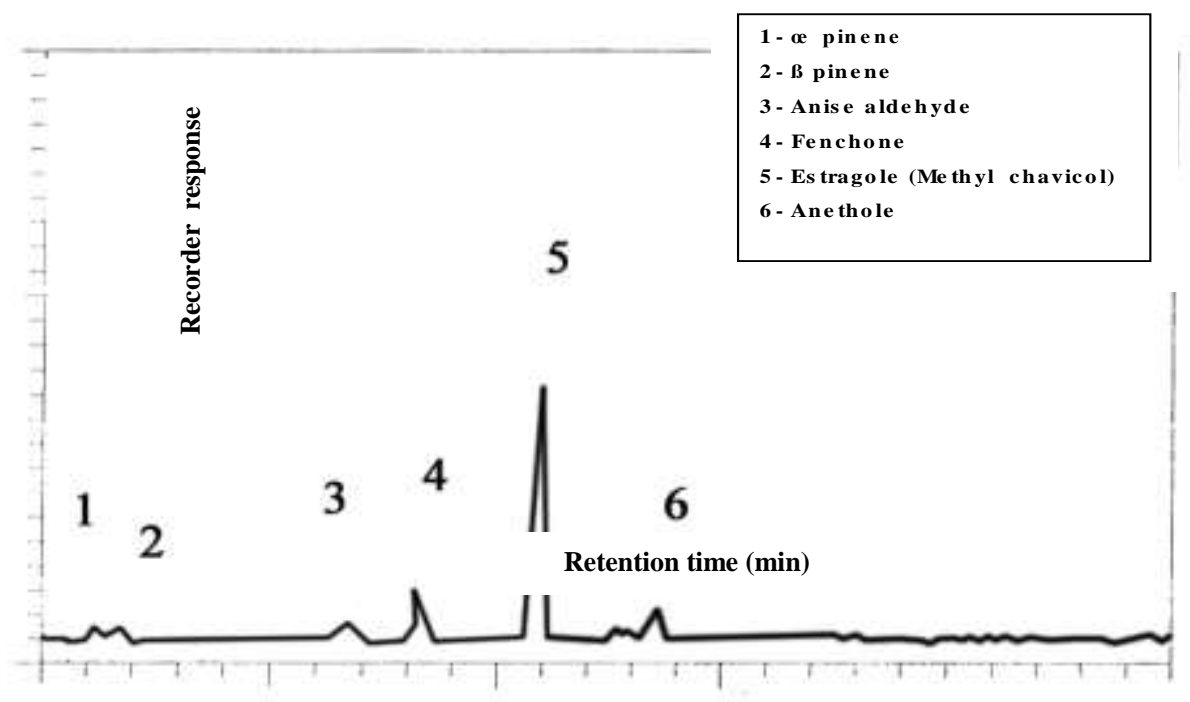

Figure 4. Chromatogram of Foeniculum vulgare, Mill essential oil distilled from plants treated with active dry yeast at $4 \mathrm{~g} / \mathrm{L}$ plus poultry manure at $20 \mathrm{~m}^{3} /$ fad. in the second season (2004/2005). 


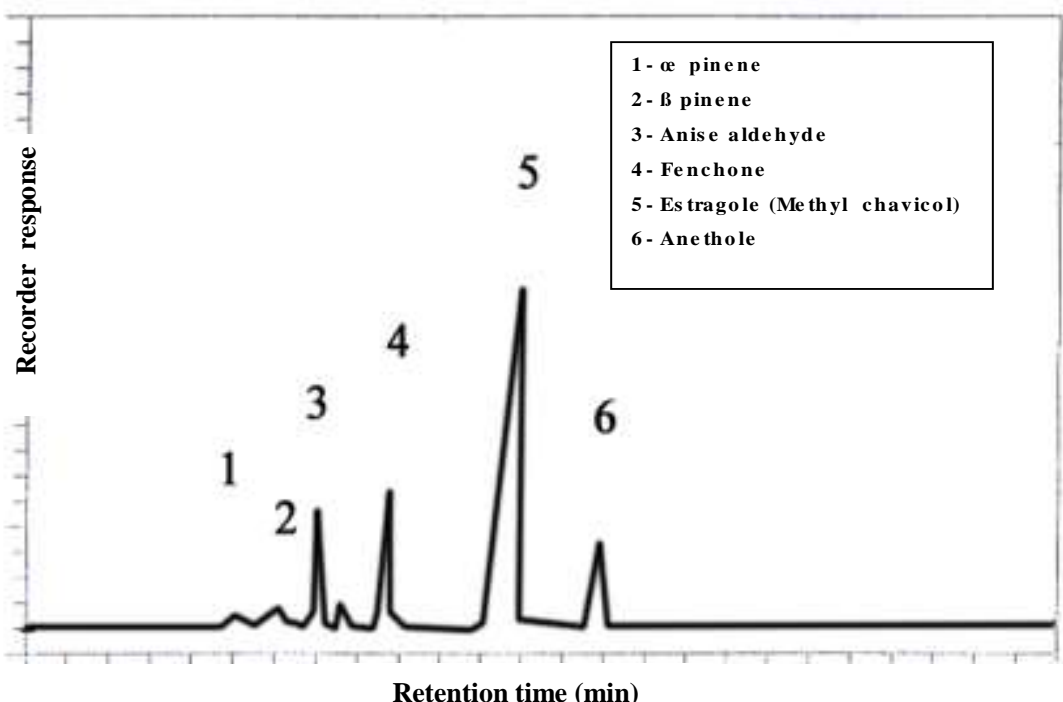

Figure 5. Chromatogram of Foeniculum vulgare, Mill essential oil distilled from plants treated with vitamin $B_{1}$ at $25 \mathrm{ppm}$ plus poultry manure at $5 \mathrm{~m}^{3} /$ fad. in the second season (2004/2005).

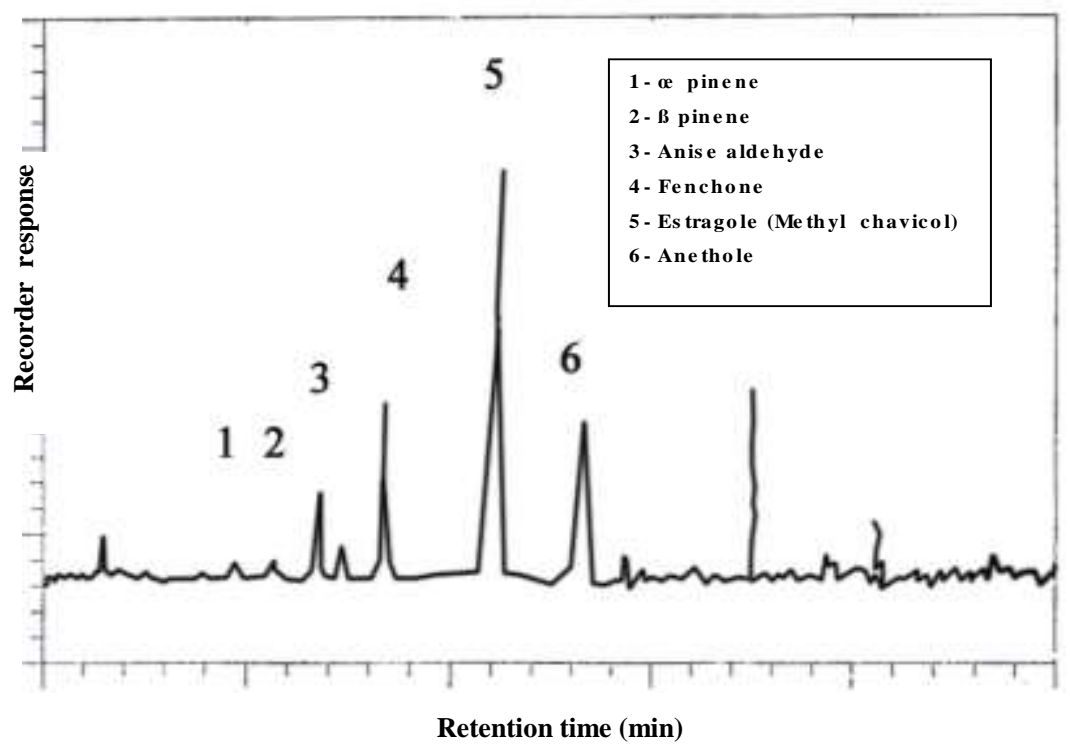

Figure 6. Chromatogram of Foeniculum vulgare, Mill essential oil distilled from plants treated with vitamin $B_{1}$ at $50 \mathrm{ppm}$ plus poultry manure at $20 \mathrm{~m}^{3} /$ fad. in the second season (2004/2005). 
at $(20,50 \mathrm{ppm})$ and nitrobein at $(500,1000 \mathrm{~g} /$ fad.). These results agreement with the findings obtained by Abd EL-Latif (2006) on Salvia officinalis, showed that, NPK application at (300:200:100) $\mathrm{kg} /$ fad. increased $\alpha$ pinene, $\beta$ - pinene, 1,8 cineole, thujone and carvacol percentages in the oil. However, active dry yeast at $5 \mathrm{~g} / \mathrm{L}$ increased camphene, camphore, borneol and menthol but it also increased $\alpha$ pinene and $\beta$ - pinene.

Concerning the interaction effect, NPK at (200:200:100) kg/fad., with poultry manure at $20 \mathrm{~m}^{3} /$ fad. increased $\alpha$ pinene , $\beta$ - pinene, anise aldehyde, fenchone, aniethole and decreased menthyl chavicol percentages in the oil in the second season compared to nitrobein application at $500 \mathrm{~g} /$ fad. plus poultry manure at $5 \mathrm{~m}^{3} / \mathrm{fad}$.

\section{Total carbohydrates percentages:}

Data presented in Table 7 showed that poultry manure at 10 or $20 \mathrm{~m}^{3} /$ fad., increased total carbohydrates in different plant organs (leaves, stems and fruits) in both first and second seasons as compared to poultry manure at $5 \mathrm{~m}^{3} /$ fad. These results are in harmony with those obtained by Abd EL-Latif (2006) who found that, the highest rate of poultry manure $\left(20 \mathrm{~m}^{3} / \mathrm{fad}\right.$.) increased total carbohydrates in leaves and stems of Salvia officinalis.

Both NPK and bio-fertilizers increased total carbohydrates percentages in leaves, stems and fruits in both two seasons. The most effective treatments were NPK at 200:200:100 and 100:100:50 kg/ fad., followed by active dry yeast at 4 and $2 \mathrm{~g} / \mathrm{L}$ compared to vitamin $\mathrm{B}_{1}$ at $(25$ or $50 \mathrm{ppm}$ ) and nitrobein at (500 or $1000 \mathrm{~g} / \mathrm{fad}$.). These results are harmony with those obtained by Abd El- Latif (2006) who found that, active dry yeast at $5 \mathrm{~g} / \mathrm{L}$ increased total carbohydrates percentages in the leaves and stems of Salvia officinalis, L.

Interaction between poultry manure at $20 \mathrm{~m}^{3} / \mathrm{fad}$. and NPK at (200:200:100) $\mathrm{kg} / \mathrm{fad}$ was the most effective treatment on increasing total carbohydrates percentages in leaves, stems and fruits compared to nitrobein at $500 \mathrm{~g} / \mathrm{fad}$. plus poultry manure at $5 \mathrm{~m}^{3} / \mathrm{fad}$. in both seasons which gave the lowest values. These results are harmony with those obtained by Ali (2002) who found that, organic and chemical fertilization increased total carbohydrates percentages in the herb and fruits of Foeniculum vulgare, Mill.

Conclusively, from these results it could be concluded that 


\section{REFERENCES}

Abd El-Azim, W. M. (2003): Production of Salvia officinalis L. plant under Sinai conditions. Ph. D. Thesis, Faculty of Agriculture, Cairo University, Egypt.

Abd EL-Ghani, Neama M. (2007): Physiological studies on rosemary and chamomile plants. M. Sc. Thesis, Faculty of Agriculture, Cairo University, Egypt.

Abd El-Latif, Esraa S. M. (2006): Effect of chemical, organic fertilizers and spraying with active dry yeast on growth, oil production and plant constituents of sage (Salvia officinialis L.) plant. M. Sc. Thesis, Faculty of Agriculture, Cairo University, Egypt.

Ali, A. F.(2001): Response of pot marigold ( Calandula officinalis, L) plants to some rock sources and yeast. Proceeding of Fifth Arabian Horticulture Conference, Ismailia, Egypt, March, 25-28: 31-42.

Ali, M. Y. M.(2002). Physiological studies on Foeniculum vulgare Mill plant under Sinai conditions. M. Sc. Thesis, Faculty of Agriculture, Cairo University, Egypt.

Amber, H.; Arvind, K.; Promod, K.and Zalar, A. (2008). Effect of nitrogen levels on growth herb yield and essential oil content of Ocimum basilicum var Gabratum (sweet basil). India Journal of Tropical Biodiversity. 15 (2): 140-143.

British Pharmacopeia (1963). Determination of Volatile Oil in Drugs. The Pharmaceutical Press, London, W.C.L.

Bunzen, J.; Guichard, N.; Labbe, J.; Prevot, P.; Sperpinet, J. and Trenchant, J.(1969). Practical Manual of Gas Chromatography. J. Trenchant Ed., EL- Seivier publ. Comp., Amesterdam, London.

El-Ghadban, E. A. E.; Kutb, S. A. and Eid, M. I.(2003). Effect of foliar spraying with active dry yeast and complete fertilizer (sengral) on growth, yield and fixed oil of (Ricinus communis L.) Egyptian Pharmaceutical Journal, 1(1): 55-66.

Guenther, E. (1961). The Essential Oils. D. Van Notrand Com., Inc., Canada, Vol. III, $4^{\text {th }}$ Ed., 399-433.

Hammam, K. A. (1996). Effect of nitrogenous fertilization and irrigation on growth, yield and active constituents of anise plants (Pimpinella anisum L.) M. Sc. Thesis, Faculty of Agriculture, Cairo University, Egypt.

Hebert, D.; Philips, P.J. and Strange, R.E. (1971). Determination of Total Carbohydrates . Methods in Microbiol., 5: 204-344. 
Jacoub, Rola W. (1999). Effect of some organic and non organic fertilization on growth, oil yield and chemical composition of Ocimum basilicum, L. and Thymus vulgaris, L. plants. Ph. D. Thesis, Faculty of Agriculture, Cairo University, Egypt.

Mohsen, Maie M. A.(2002). Sweet basil herb and oil production as affected by chemical and organic fertilization . M. Sc. Thesis, Faculty of Agriculture, Cairo University, Egypt.

Mona, Y.K.; Kandil, M.A.M. and Hend, M.F.S. (2008). Effect of three different compost levels on fennel and salvia growth character and their essential oils. Research Journal of Agriculture and Biological Sciences, 4 (1): 34-39.

Morelli, L.; Bonan, E.; Pagni, A.M. and Tomei, P.E. (1983). School of specialization Science and technology of medicinal plants. Faculty of Pharmacy, University of Piso., Food and Agriculture, Organization of United Nations, Rome, 61-63.

Sakr, W. R. A.(2001). Effect of some organic and inorganic fertilizers on Mentha piperita. M. Sc. Thesis Faculty of Agriculture, Cairo University, Egypt.

.Salman, A.S.(2004): Effect of biofertilization on Ocimum basilicum, L. plant. M. Sc. Thesis, Faculty of Agriculture, Cairo University, Egypt.

Snedecor, G.W. and Cochran, W.G.(1972): Statistical Methods. (6 ${ }^{\text {th }}$ Ed.) Iowa stat. Univ. Press. Ames. Iowa U.S.A. 953. 


\section{تأثير التسميد العضوي والحيوي على النمو والمحصول والمكونات الكيماوية فِي نبات الثمر الثمر}
عبد الغفور عوض السيد*، أحمد سلامة الليثى*، ربيع محمد مصطفى** وحنان

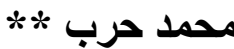

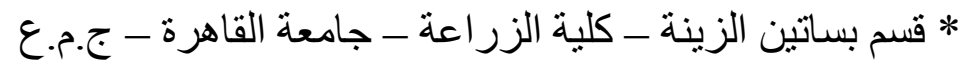

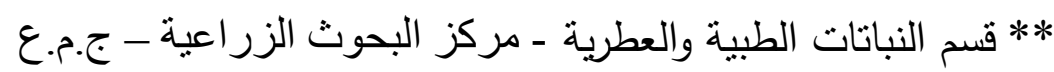

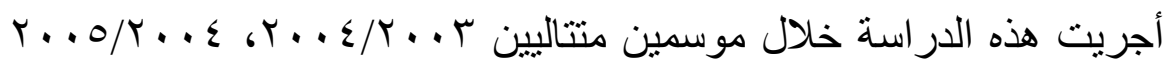

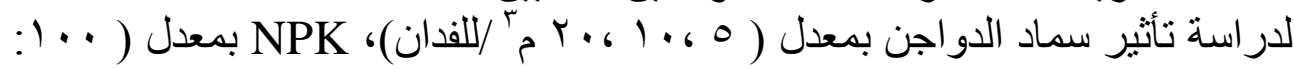

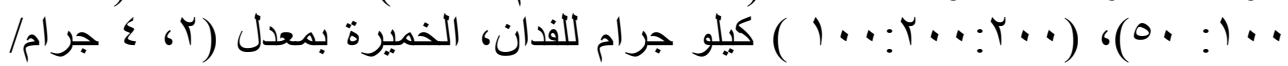

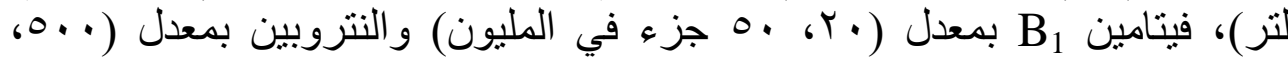

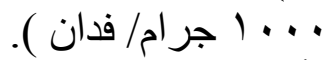

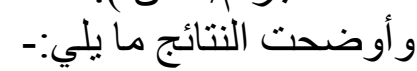

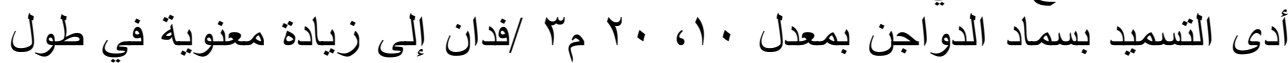

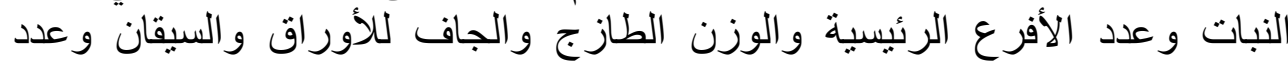

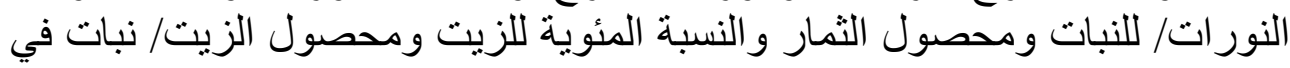

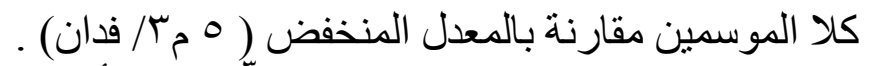

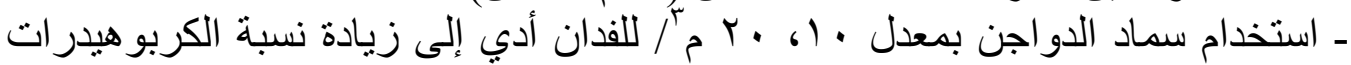

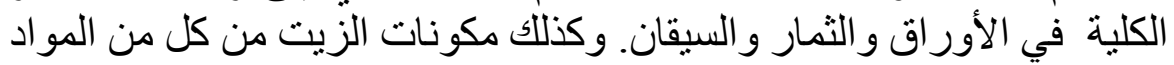
$\alpha$ pinene, $\beta$ - pinene, anise aldehyde, fenchone and anethole وتقاليل نسبة لـ

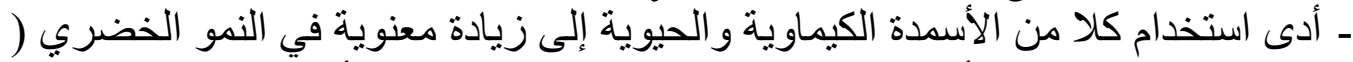

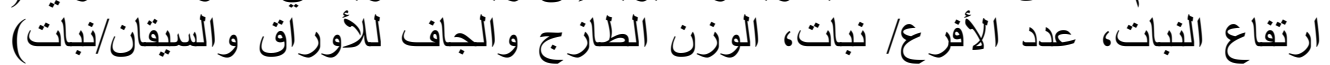

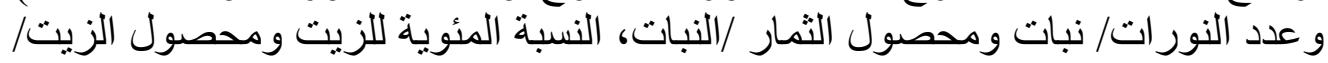

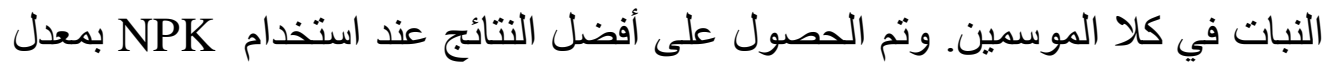

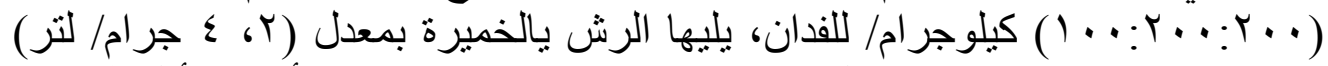

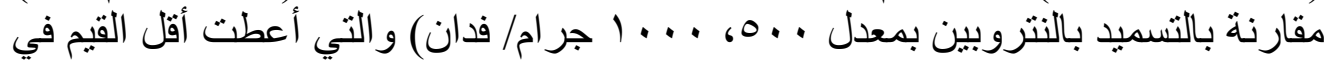

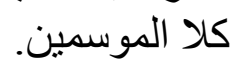

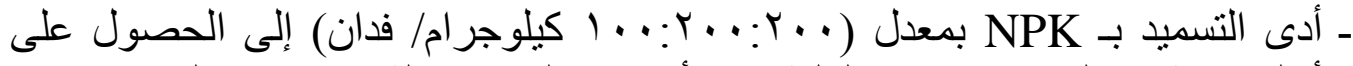

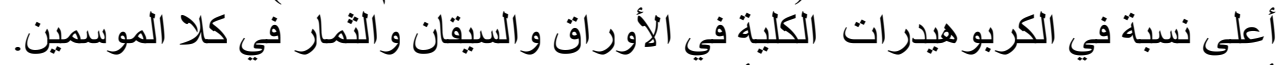

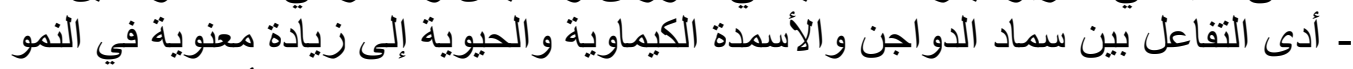

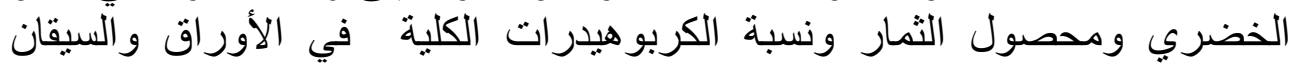
و الثمار وإنتاج الزيت وزيادة نسبة anethole به في كلا الموسمين. 